\title{
New antiviral agents and new treatments on the horizon for the management of viral hepatitis
}

\author{
M. Sönmezoğlu \\ Yeditepe University Hospital, Infectious Diseases Department, Istanbul, Turkey
}

\begin{abstract}
Transfusion dependant patients are at risk of acquiring transfusiontransmitted viral infections including Hepatitis B virus (HBV) and Hepatitis C (HCV). These infections can lead to cirrhosis and hepatic cancer. Standard treatment, although with improved therapeutic results still exhibits resistance and relapses. New antiviral agents have been developed to further improve results and reduce adverse events. For hepatitis $B$, along with pegylated interferon $\alpha-2 \alpha$, other drugs that have been approved include lamivudine, adefovir, entecavir, telbivudine and tenofovir, while emtricitabine and clevudine are awaiting FDA approval. Possible combination drug therapy may improve efficacy without engendering resistance. For hepatitis $\mathrm{C}$, standard therapy has been the combination of Peg-IFN/Ribavarin. Genotype 1 of the virus, which is widespread in the USA and Europe, can be resistant to treatment especially with high viral load. Directly acting antiviral agents (DAAs), are being developed. These are: i) HCV NS3 protease inhibitors, such as telaprevir and boceprevir, which are currently approved by the FDA. Several other compounds are in phase I-II development; ii) NS5B polymerase inhibitors, which target HCV replication. These include mericitabine (a nucleoside analogue inhibitor) currently in phase III trials, and nonnucleiside inhibitors; iii) New intreferons such as pgylated interferon$\lambda$, which are also on trial. Triple therapy using pegylated IFN$\alpha /$ Ribavarin along with telaprevir or boceprevir are also under trial.
\end{abstract}

\section{Introduction}

Transfusion dependant patients are at risk of having transfusiontransmitted infections.

Correspondence: M. Sönmezo lu, Yeditepe University Hospital, Infectious Diseases Department, Istanbul, Turkey.

Key words: viral, hepatitis, antiviral agents.

(C) Copyright M. Sönmezoğlu, 2011

Licensee PAGEPress, Italy

Thalassemia Reports 2011; 1(s2):e27

doi:10.4081/thal.2011.s2.e27

This article is distributed under the terms of the Creative Commons Attribution Noncommercial License (by-nc 3.0) which permits any noncommercial use, distribution, and reproduction in any medium, provided the original author(s) and source are credited.

Parts of this work were presented at the "12th International Conference on Thalassemia and Hemoglobinopathies", Antalya (Turkey), 11-14 May 2011.
Transfusion-transmitted viral infections, particularly hepatitis C, following hepatitis B can lead to liver cirrhosis and hepatocellular carcinoma (HCC). Hepatitis B (HBV) and C (HCV) are viral infections which can cause acute and chronic hepatitis and are the leading causes for hepatic cirrhosis and cancer, thus creating a significant burden to healthcare systems due to the high morbidity/mortality and costs of treatment.

\section{Hepatitis B}

According to the World Health Organization (WHO), one third of the world's population has been infected with HBV, and more than 350 million suffer from chronic infection. Approximately 15-40\% of infected patients will develop cirrhosis, liver failure or hepatocellular carcinoma. HBV accounts for an estimated 600.000 deaths each year, mainly due to the consequences of chronic hepatitis, such as cirrhosis and liver cancer. HBV can effectively be prevented by vaccination.

\section{Treatment of Hepatitis B}

Seven drugs are licensed for the treatment of HBV infection: interferon $\alpha$, pegylated interferon $\alpha-2 \alpha$, lamivudine, adefovir, entecavir, telbivudine, and tenofovir.

Two other oral agents that appear to be efficacious against HBV but are not yet approved by the Food and Drug Administration are emtricitabine and clevudine. Emtricitabine, which is similar in structure, efficacy, and resistance profile to lamivudine, appears to confer no advantage over lamivudine. Clevudine is distinguished from other oral agents by its sustained suppression of HBV- DNA for several months after cessation of therapy. However, preliminary clinical trials suggest that clevudine is less potent than other oral agents in suppressing $\mathrm{HBV}$ DNA and inducing HBeAg seroconversion. ${ }^{1}$

In the future, new antiviral drug regimens are expected to improve in efficacy without engendering resistance, and combination drug therapy may contribute to this evolution.

These regimens could develop shorter treatment courses with more sustained clinical outcomes. ${ }^{1}$

\section{Treatment of Hepatitis C}

It has been estimated that over 180 million persons have chronic infection and that three to four million new cases occur each year. According to the European Centre for Disease Prevention and Control Technical Report, there is a significant diverse burden of infection and disease due to hepatitis $\mathrm{B}$ and hepatitis $\mathrm{C}$ in the EU/EEA and in the neighborhood. ${ }^{2,3}$

\section{Standard of Care for hepatitis C}

The combination therapy of Peg-IFN/Ribavarin (RBV), which is currently the standard antiviral therapy for hepatitis $\mathrm{C}$, shows dramatically improved therapeutic results. The primary goal of HCV therapy is to cure the infection, which results in eliminating detectable circulating HCV after cessation of treatment. Unlike hepatitis B, hepatitis C is now a curable disease with current treatments. However, genotype 1 , which is particularly widespread in the United States and Europe, with high viral load can be resistant to treatment. ${ }^{4}$ Therefore, intensive 
efforts have been made to develop directly acting antiviral agents (DAAs) against HCV (Table 1). Many of these DAAs are currently in phase I-III development and will significantly change treatment options for HCV infection in the near future. The most advanced compounds are telaprevir and boceprevir, which are both inhibitors of the HCV NS3 protease and have been shown to significantly enhance SVR rates in HCV genotype 1 patients when applied in addition to pegIFN- $\alpha$ and ribavirin. ${ }^{5}$

\section{New viral agents}

New pharmaceutical agents for treating hepatitis $\mathrm{C}$ currently in development include; new pharmaceutical formulations of IFN aimed at enhancing antiviral activity, RBV pro-drugs, protease inhibitors and polymerase inhibitors that are HCV-selective antiviral agents, and various others aimed at enhancing immunostimulatory activity. ${ }^{3}$

\section{NS3/4A protease inhibitors}

Telaprevir and boceprevir are the most advanced NS3/4A protease inhibitors, and are currently (May 2011) approved for the treatment of hepatitis $\mathrm{C}$ by the FDA. Current study results show that combining protease inhibitors with Peg-IFN/RBV can control the mutant virus that are resistant to protease inhibitors, providing strong antiviral effect.

\section{Telaprevir (VX-950)}

Telaprevir is an orally bioavailable NS3 protease inhibitor, and combined with pegIFN/RBV for genotype 1 patients. Duration and strategy (fixed vs response-guided duration) was evaluated for treatment-naive patients in phase III registration trial. SVR rates of $69 \%$ to $75 \%$ were reported. This may allow shortening therapy from 48 to 24 weeks in some patients. The most important side effects of telaprevir are rash, gastrointestinal disorders and anemia. Although; severe rash may require treatment discontinuation.

\section{Boceprevir (SCH 503034)}

HCV genotype 1 patients with prior failure on standard therapy revealed that boceprevir monotherapy and combination therapy with pegIFN- $\alpha-2 b$ resulted in mean maximum reductions in HCV RNA load. Boceprevir was well-tolerated alone and in combination with pegIFN- $\alpha$ 2b. However, viral breakthrough due to selection of pre-existing resistant mutants was observed in some patients, in particular during boceprevir monotherapy. Duration and strategy (fixed vs responseguided duration) evaluated for treatment-naive patients in phase III trial and SVR rates of $63 \%$ to $66 \%$ reported. The most common side effects related to boceprevir were anaemia, nausea, vomiting and dysgeusia.

\section{Other NS3 protease inhibitors}

Other NS3 protease inhibitors are currently in phase I-II development (R7227/TTMN191, MK7009, BI201335, TMC435350, SCH900518, BMS-650032, PHX1766, ACH-1625). In general, they exhibit a high antiviral activity in HCV genotype 1 patients, similar to telaprevir and boceprevir. Potential advantages of these second-wave protease inhibitors might be better tolerability, broader genotypic activity and/or improved pharmacokinetics, which may allow a once-daily dosage. ${ }^{4}$

Table 1. Drug candidates for treating HCV infection 2011. (from Nature $2011 \mathrm{New}$ drugs hit the target. Vol 474).

\begin{tabular}{|c|c|c|c|c|c|c|c|c|}
\hline \multirow[b]{2}{*}{ Mechanism } & \multicolumn{4}{|c|}{ Direct-acting antiviral agents } & \multicolumn{4}{|c|}{ Host-targeting agents } \\
\hline & $\begin{array}{l}\text { Inhibitor of } \\
\text { polyprotein } \\
\text { processing }\end{array}$ & Inhibitor o & HCV replication & & $\begin{array}{l}\text { Anti- } \\
\text { apoptotic } \\
\text { agent }\end{array}$ & $\begin{array}{l}\text { Antiviral } \\
\text { agent }\end{array}$ & $\begin{array}{c}\text { Immunomodulatory } \\
\text { agent }\end{array}$ & $\begin{array}{c}\text { Inhibitor of virus } \\
\text { fusion with host } \\
\text { cell }\end{array}$ \\
\hline \multirow[t]{2}{*}{ Target } & \multirow{2}{*}{$\begin{array}{c}\text { NS3 or NS3/NS4A } \\
\text { protease }\end{array}$} & \multirow[t]{2}{*}{ NS5A } & \multicolumn{2}{|c|}{ NS5B polymerase } & \multirow[t]{2}{*}{ Caspases } & \multirow[t]{2}{*}{ Cyclophilins } & \multirow[t]{2}{*}{ Interferons } & \multirow[t]{2}{*}{ Viral entry } \\
\hline & & & $\begin{array}{l}\text { Nucleoside } \\
\text { analogue }\end{array}$ & $\begin{array}{l}\text { Non-nucleoside } \\
\text { inhibitor }\end{array}$ & & & & \\
\hline $\begin{array}{l}\text { Recently } \\
\text { approved }\end{array}$ & $\begin{array}{l}\text { Telaprevir (Vertex) } \\
\text { Boceprevir (Merck) }\end{array}$ & None & None & None & None & None & None & None \\
\hline Phase III & $\begin{array}{c}\text { TMC435 } \\
\text { (Tibotec and Medivir) } \\
\text { B1201335 } \\
\text { (Boehringer Ingelheim) }\end{array}$ & None & None & None & None & $\begin{array}{l}\text { Alisporivir } \\
\text { (DEBO25: } \\
\text { Novartis) }\end{array}$ & None & None \\
\hline Phase II & $\begin{array}{c}\text { ACH-1625 (Achillion) } \\
\text { BMS-650032 } \\
\text { (Bristol-Myers Squibb) } \\
\text { BMS-791325 } \\
\text { (Bristol-Myers Squibb) } \\
\text { Danoprevir } \\
\text { (RG7227: Roche) } \\
\text { GS-9256 (Gilead) } \\
\text { GS-9451 (Gilesd) } \\
\text { ABT-450/r } \\
\text { (Abbott and Enanta) } \\
\text { Vaniprevir } \\
\text { (MK-7009: Merck) }\end{array}$ & $\begin{array}{l}\text { ABT-267 (Abbott) } \\
\text { BMS-790052 } \\
\text { (Bristol-Myers Squibb) } \\
\text { GS-5885 (Gilead) }\end{array}$ & $\begin{array}{c}\text { IDX184 (Idenix) } \\
\text { Mericitabine } \\
\text { (RG7128; Roche) } \\
\text { PSI-7977 and } \\
\text { PSI-7851 } \\
\text { (Pharmasset) } \\
\text { RG7128 } \\
\text { (Roche and } \\
\text { Pharmasset) }\end{array}$ & $\begin{array}{l}\text { ABT-333 (Abbott) } \\
\text { ABT-072 (Abbott) } \\
\text { ANA598 (Anadys) } \\
\text { BI207127 } \\
\text { (Boehringer } \\
\text { Ingelheim) } \\
\text { Filibuvir (Ptizer) } \\
\text { IDX375 (Idenix) } \\
\text { Tegobuvir } \\
\text { (GS-9190: Gileod) } \\
\text { VCH-916 (Vertex) } \\
\text { VX-222 (Nertex) }\end{array}$ & $\begin{array}{l}\text { IDN-6556 } \\
\text { (Idun/Conatus) }\end{array}$ & $\begin{array}{l}\text { NIM811 } \\
\text { (Novartis) } \\
\text { SCY-635 } \\
\text { (Scynexis) }\end{array}$ & $\begin{array}{c}\text { PEGylated } \\
\text { interferon-A } \\
\text { (Bristol-Myers Squibb) }\end{array}$ & None \\
\hline Phase I & $\begin{array}{l}\text { GSK2336805 } \\
\text { (GlaxoSmithKline) } \\
\text { IDX320 (Idenix) } \\
\text { MK-5172 (Merck) } \\
\text { VX-985 (Nertex) }\end{array}$ & $\begin{array}{l}\text { AZD7295 (AstraZeneca) } \\
\text { PPI-461 (Presidio) }\end{array}$ & $\begin{array}{c}\text { GS-6620 } \\
\text { (Gilead) } \\
\text { INX-08189 } \\
\text { (lnhibite) } \\
\text { PSI-938 } \\
\text { (Pharmasset) }\end{array}$ & $\begin{array}{l}\text { GSK2485852 } \\
\text { (GlaxoSmithKline) } \\
\text { VX-759 } \\
\text { (NCH-759; Vertex) } \\
\text { GS-9669 (Gilead) }\end{array}$ & None & None & $\begin{array}{c}\text { GS-9620 } \\
\text { (Gilead) }\end{array}$ & ITX-5061 (iTherX) \\
\hline Preclinical & $\begin{array}{c}\text { ACH-1095 (Achillion) } \\
\text { ACH-2684 (Achillion) } \\
\text { AVL-192 (Avila) } \\
\text { GNS-227 } \\
\text { (GenoScience Pharma) }\end{array}$ & $\begin{array}{c}\text { ACH-2928 (Achillion) } \\
\text { BMS-766 (Bristol-Myers Squibb) } \\
\text { EDP-239 (Enanta) } \\
\text { IDX380 and IDX719 (Idenix) } \\
\text { PPI-437, PPI-668, PPI-833 } \\
\text { and PPI-1301 (Presidio) }\end{array}$ & $\begin{array}{c}\text { PSI-661 } \\
\text { (Pharmasset) }\end{array}$ & $\begin{array}{l}\text { BILB } 1941 \\
\text { (Boehringer } \\
\text { Ingelheim) }\end{array}$ & None & None & None & $\begin{array}{c}\text { ITX4520 } \\
\text { (TherX) PRO } \\
206 \text { (discontinued: } \\
\text { Progenics) } \\
\text { REP } 9 \text { C (REPLICor) } \\
\text { SP-30 (Samaritan) }\end{array}$ \\
\hline
\end{tabular}




\section{Compounds targeting hepatitis $\mathbf{C}$ virus replication}

\section{NS5B Polymerase Inhibitors}

NS5B RNA polymerase inhibitors are in two classes: Nucleoside analogue inhibitors (NAIs) and non-nucleoside inhibitors (NNIs).

NAIs are incorporated into the growing RNA chain, thus causing direct chain termination by tackling the active site of NS5B37-48. As the active centre of NS5B is a highly conserved region of the HCV genome, NAIs are potentially effective against all different genotypes, in contrast to NS3/4A inhibitors. There is a relatively high genetic barrier in the development of resistance to NAIs. ${ }^{5}$ In this class, phase III trials of mericitabine is about to start. Although mericitabine is slightly less effective than the protease inhibitors, it seems to be a safe drug with a high barrier to resistance.

NNIs bind to different allosteric enzyme sites, which results in conformational protein change before the elongation complex is formed. As NNIs bind distantly to the active centre of NS5B, their use results more frequently in resistance development than during treatment with NAIs. ${ }^{5}$

\section{NS5A inhibitors}

In a ascending-dose study, it was shown that inhibition of the NS5A protein with BMS-790052 leads to a sharp initial decline of HCV RNA concentrations, but combination therapy studies are awaited.

More than 50 other drugs are, in the research and development pipeline (Table 1) Many of these are in new classes and can be combined to create antiviral combination, limiting the emergence of drug resistance. ${ }^{6}$

\section{New interferons}

A variant called pegylated interferon- $\lambda$, which is designed to be more potent and safer than interferon- $\alpha$ has been developed. Interferon- $\lambda$ docks with different receptors that are less common than the receptors for interferon- $\alpha$. This interferon circumvents the bone marrow and therefore avoids anaemia and flu-like symptoms, so it might be a good partner for direct-acting antivirals.

\section{Perspective of triple therapy of HCV}

Phase III clinical trials combining pegylated interferon- $\alpha$, ribavirin, and a direct acting antiviral of the HCV protease inhibitor family (telaprevir or boceprevir) have been completed. These data will likely lead to the approval of a triple therapy in patients infected with HCV genotype 1 who are treatment-naïve or had nonresponse to a prior course of pegylated interferon- $\alpha$ and ribavirin. ${ }^{7}$ The pivotal trials with telaprevir and boceprevir have confirmed that a significantly higher proportion of naïve and non-responder patients with genotype 1 infection have an SVR, with response-guided therapy. In a proportion of patients with satisfactory early responses, treatment can be significantly shortened. ${ }^{8-11}$

\section{References}

1. Dienstag JL. Hepatitis B virus infection. N Engl J Med 2008;359:1486-500.

2. European centre for disease prevention and control. Hepatitis B and $\mathrm{C}$ in the EU neighbourhood: prevalence, burden of disease and screening policies. Stockholm: ECDC; 2010.

3 European centre for disease prevention and control. Hepatitis B and $\mathrm{C}$, Current situation in EU/EEA; 2010.

4 Hayashi N, Hiramatsu N, Oze T. Interferon therapy and new antiviral drugs for chronic hepatitis C. JMAJ 2010;53:229-235.

5 Lange CM, Sarrazin C, Zeuzem S. Direct antiviral agents for hepatitis C - New developments. European gastroenterology \& hepatology review, 2010;6:70-6.

6 Schlütter J. New drugs hit the target. Nature. 2011;474:5-7.

7 EASL clinical practice guidelines: Management of hepatitis $\mathrm{C}$ virus infection. European association for the study of the liver. J Hepatol 2011;55:245-264.

8 Bacon BR, Gordon SC, Lawitz E, et al. HCV RESPOND-2 final results: high sustained virologic response among genotypel previous nonresponders and relapsers to peginterferon/ribavirin when retreated with boceprevir plus PegIntron/ribavirin. Hepatology 2010;52:430A.

9 Jacobson IM, McHutchison JG, Dusheiko GM, et al. Telaprevir in combination with peginterferon and ribavirin in genotype $1 \mathrm{HCV}$ treatment-naive patients: final results of Phase 3 ADVANCE study. Hepatology 2010;52:427A.

10 Poordad F, McCone J, Bacon BR, et al. Boceprevir (BOC) combined with peginterferon $\alpha-2 \mathrm{~b} /$ ribavirin (P/R) for treatment-naive patients with hepatitis $\mathrm{C}(\mathrm{HCV})$ genotype 1: SPRINT-2 final results. Hepatology 2010;52:402A.

11 Sherman KE, Flamm SL, Afdhal NH, et al. Telaprevir in combination with peginterferon $\alpha 2 \mathrm{~b}$ and ribavirin for 24 or 48 weeks in treatment-naive genotype $1 \mathrm{HCV}$ patients who achieved an extended rapid viral response: final results of Phase 3 ILLUMINATE study. Hepatology 2010;52:401A. 